\title{
INVESTIGATION OF PERFORMANCE OF SOLAR-ASSISTED HEAT PUMP SYSTEMS: MUĞLA EXAMPLE
}

\author{
Tolga URAL, \\ Department of Energy Systems Engineering, Technology Faculty, Muğla Sıtkı Koçman University, Turkey, tolgaural@mu.edu.tr \\ (iD) https://orcid.org/0000-0002-1871-8569 \\ Gülșah KARACA, \\ Department of Energy Systems Engineering, Technology Faculty, Gazi University, Turkey, gulsahkaraca@mu.edu.tr \\ iD https://orcid.org/0000-0002-6219-6016 \\ Received: 26.02.2018, Accepted: 10.06.2018 \\ Research Article \\ *Corresponding author \\ DOI:10.22531/muglajsci.429036
}

\begin{abstract}
In this study, the combination of solar thermal systems with heat pump has been investigated numerically. The potential utility of the collectors is found by comparing heat pump systems with combined systems. All simulations for the Muğla province were made using the POLYSUN program. The simulated systems are designed to meet the demand for hot water and residential heating of single-dwelling houses. The results of this study show that the seasonal performance factor of the system increases as the collector field added to the air source heat pump system increases. However, in the systems where the heat demand is met, the heating effect coefficient of the heat pump ( $\left.C O P_{H P}\right)$ decreases. In this system, solar energy is used to meet the need for hot water, while also supporting housing heating. However, it has been determined that the heat pump should be selected at a sufficient capacity because the increase in the number of collectors by selecting the heat pump at the insufficient capacity cannot meet the demand. However, it has been determined that the heat pump should be selected at a sufficient capacity because the increase in the number of collectors by selecting the heat pump at the insufficient capacity cannot meet the demand. In the systems where the heat demand cannot be met, the heating effect coefficient after 2 collectors is found to be constant. Collectors used in excess of 2 collectors are closed when there is no need for them. However, it supports heating in winter.
\end{abstract}

Keywords: Heating system, heat pump, solar collector, heating performance, case study

\section{GÜNEŞ ENERJISİ DESTEKLİ ISI POMPASI SISTEMLERININN PERFORMANSININ İNCELENMESI: MUĞLA ÖRNEĞİ}

\section{Öz}

Bu çalışmada solar termal sistemlerin ısı pompası ile kombinasyonu sayısal olarak incelenmiştir. Kollektörlerin potansiyel faydası ısı pompası sistemleri kombine sistemlerle karşılaştırılarak bulunmuştur. Muğla ili için tüm simülasyonlar POLYSUN programı kullanılarak yapılmıştır. Simülasyonu yapılan sistemler tek haneli konutların kullanım sicak suyu ve konut ısıtması ihtiyacını karşılayacak şekilde tasarlanmıştır. Bu çalışmanın sonuçları sistemin mevsimsel performans faktörünün hava kaynaklı ısı pompası sistemine eklenen kollektör alanı arttıkça arttığını göstermektedir. Ancak ısı talebinin karşılandığı sistemlerde ısı pompasının ısıtma tesir katsayısının azaldığı sonucuna ulaşılmıştır. Bu sistemde solar enerji sıcak su ihtiyacını karşılamak için kullanılırken bir taraftan da konut ısıtılmasına destek olmaktadır. Ancak yetersiz kapasitede ısı pompası seçilerek kollektör sayısının arttırılmasının talebi karşılamadığı bu nedenle yeterli kapasitede ısı pompası seçilmesi gerektiği saptanmıştır. Isı talebinin karşılanamadığı sistemlerde ise 2 kollektörden sonra isıtma tesir katsayısının sabit kaldığı görülmüştür. 2 kollektörden fazla sayıda kullanılan kollektörler yazın ihtiyaç fazlalı̆̆ından kapatılmaktadır. Ancak kış döneminde ısıtmaya destek olmaktadır.

Anahtar Kelimeler: Isıtma sistemi, ısı pompası, güneş kollektörü, ısıtma performansı, durum çalışması

Cite

Ural, T., Karaca, G., (2018). "Investigation of performance of solar-assisted heat pump systems: Muğla example”, Mugla Journal of Science and Technology, 4(1), 123-129.

\section{Introduction}

Fossil fuel consumption is prohibited in order to prevent air pollution in coastal areas of Muğla. For this reason, alternative combustion systems were needed. In this case, despite the fact that the heat pumps are an attractive opportunity, it is a disadvantage that the electricity consumption of this device in Muğla conditions is unknown. Heat demand and heat loss calculations can be used to calculate annual electricity consumption without using a program and annual invoicing can be done. Heat demand and heat loss calculations were made and introduced to the POLYSUN 
program. POLYSUN is a program that calculates the electricity energy needed according to the yearly outdoor air temperature, solar radiation and indoor temperature instantly according to the time. In addition, domestic hot water is calculated according to the municipal water temperature during the summer and winter months. In the program, the coverage ratio is calculated according to the number of selected collectors. This is how many collectors should be used in the system.

When the literature is searched, Dikici (2004) studies the heating effect coefficient of the system (COP) with different combinations of heat pumps for the heating of the houses. As a result of these experiments, it is seen that the systems with the highest heating coefficient of performance among these six combinations are Earthbased heat pump $\left(\mathrm{COP}_{\text {system }}=1.63\right)$ in December, Solar and air heat pump in January $\left(\mathrm{COP}_{\text {system }}=3.43\right)$, solar and earth-based heat pumps in February and March, (COP system values of 3.34 and 3.06 respectively) came to the conclusion [1]. Gündüz (2007) studied the working principle of solar energy supported heat pump and system elements in Bilecik province theoretically. They used water-source solar collectors and heat pumps to heat a building and to meet the need for domestic hot water. The heat load in the evaporator was $6.04 \mathrm{~kW}$, the electric power drawn by the compressor was $384 \mathrm{~kW}$. She stated that the system would need an additional heater in December, January, February, March, April, May and June and she found that the system's COP value as 3.1 [2]. Açıkgöz (2007) calculated the support of solar energy in a composite energy power system. In the first case, only the heat pump is used to heat and cool the building. In the second case, the solar energy-supported earth-source heat pump is used. The heating of the building and the need for domestic hot water were met using a heat pump and two solar collectors, respectively. 25 collectors were added as a third option to the heat pump system to support both to heat domestic hot water and the heating. He compared this three options and conclude that it is better to use solar collectors only for domestic hot water [3]. Liang et al. (2011) reviewed solar assisted air source heat pump for Nanjing to improve the performance of the heating system with the help of a mathematical model. The COP of the heat pump increased during the heating season, depending on the solar radiation intensity and the solar collector area. When the collector area is increased from $0 \mathrm{~m}^{2}$ to $40 \mathrm{~m}^{2}$ during the heating season, $453.43 \mathrm{kWh}$ of energy is saved with $9.9 \%$ energy saving ratio [4]. Deng et al. (2012) simulated and optimized the system consisting of solar collectors and heat pump. The average COP of the heat pump was found to be 2.38 and the solar collector's share in the system to be $69 \%$ for the whole heating season [5]. Aydin (2013) used vacuum tube collectors and airsource heat pump to perform experiments in Karabük for 3 days in April between 10:30 am-04:00 pm. Aydin (2013) used vacuum tube collectors and air-source heat pump to perform experiments in Karabük for 3 days in April between 10:30 am-04:00 pm. He placed the evaporator of the heat pump in the storage tank of the collector. On sunny days, he examined the temperature change in the collector store by time and on cloudy days repeated this experiment only with heat pump. The COP of the heat pump was found to be 2.072 on sunny days and 1.43 on cloudy days. He concluded that $45 \%$ increase in system efficiency by using solar collectors [6].

Carbonell et al. (2014) examined the potential utility of heat pumps combined with the solar thermal system to heating and preparation of domestic hot water. They used POLYSUN simulation program to compare heat pump and combined system in detached houses in different climates in Europe [7]. González and Yousif (2015) paid attention to energy efficiency measures in order to be able to get a net zero energy hotel in Gozo in the center of the Mediterranean. They used POLYSUN software to evaluate the performance of sustainable energy and high efficiency systems [8]. Good et al. (2015) have compared different solar energy solutions for net zero-energy Norwegian buildings using the POLYSUN simulation program [9]. Bessa and Prado (2015) compared passive technologies and solar water heating systems used to reduce carbon dioxide emissions in homes. They simulated solar water heating systems in Dimensol, EnergyPlus, F-Chart, Polysun, RETScreen, SAM, Transol, T*Sol and Watsun programs [10]. Ghafoor and Fracastoro (2015) used the POLYSUN program in their multi-purpose solar thermal systems to compare their cost effectiveness with multi-purpose PV based heat pumps [11]. Shipkovs et al. (2015) assessed the models found in the POLYSUN program in the northern latitudes and developed a dynamic simulation program containing 5 years of meteorological data. They optimized the solar cooling system using multiple simulations. They evaluated the effect of different elements of the system on the operating performance and developed the most suitable model for the given climate conditions [12]. Good et al. (2014) used POLYSUN and PVsyst programs to optimize the solar energy potential in buildings [13]. Bornatico et al. (2013) created a model for rapid optimization of energy systems. To test the correctness of the model, they simulated the system in POLYSUN and TRNSYS programs and observed that the results were close to each other [14].

When previous studies examined, using of the POLYSUN simulation program in Turkey conditions were found rarely. The purpose of this study that demand of heating and domestic hot water investigate with POLYSUN simulation program for Muğla province in Turkey. Muğla has the highest average annual solar radiation in Turkey with $5277 \mathrm{Wh} / \mathrm{m}^{2}$ / day. Using solar energy actively and effectively in heating of building and domestic hot water is necessary in province, where has a relatively advantageous position and climate. An analysis was carried out assuming that 50 liters of hot water per person was consumed in a single-family residence where four people live. Heating of house was provided with air source heat pump, the accumulation tank and water 
assisted. The heating of the house was provided by heating the water in the accumulation tank with solar collectors and an air source heat pump. In this study, heat pump and solar collectors were used in the heating system. Models created by modifying the solar collector area and heat pump capacity have been examined. Thus, the importance of solar energy for Muğla is better understood.

\section{Material and Method}

A villa was investigated in coastal areas where the use of coal is prohibited and the natural gas does not reach it. Air-source heat pumps and flat plate solar collectors were chosen for the heating system. Models for the heating of the house and the preparation of domestic hot water were examined with the POLYSUN simulation program. Collector area and heat pump capacity were changed in the created models. The percentage of additive in the water heating of the collectors was examined. Firstly by reducing the heat pump capacity and by increasing the collector area and secondly by increasing the heat pump capacity and the reduction of the collector area were investigated and it has been observed which gives the best results. Collector area and heat pump capacity were changed in the created models. The percentage of additive in the water heating of the collectors was examined. Firstly by reducing the heat pump capacity and by increasing the collector area and secondly by increasing the heat pump capacity and the reduction of the collector area were investigated and it observed which gives the best results. In this context, airto-water heat pumps have been investigated at five different capacities as $6.51 \mathrm{~kW}, 7.98 \mathrm{~kW}, 9.95 \mathrm{~kW}, 12.54$ $\mathrm{kW}$ and $15.34 \mathrm{~kW}$. Another parameter used in simulation is the collector field. The solar collectors used are flat plate and the numbers between 0 and 10 range between 0 and $20 \mathrm{~m}^{2}$. The system model used to meet the villa's thermal energy requirement is shown in Fig. 1.

The values entered in the simulation program are heat demand, heat loss, and number of people, domestic hot water temperature, and location, outside temperature, global radiation and wind speed. Once these values are entered, the appropriate heat pump, tank, solar collectors and heater (radiator) are selected for the heating system. For different system combinations, the total energy ( $\left.Q_{u s e}\right)$ given to the system, the total amount of electricity consumed ( $\left.E_{t o t}\right)$, the thermal energy ( $\left.Q_{h p}\right)$ given to the system by the heat pump, the electric charge and the coefficient of performance, the seasonal performance factor, the percentage of contribution of solar energy on the heating and hot water supply system $\left(\mathrm{SF}_{\mathrm{n}}\right)$, the percentage change in the total consumed electricity and performance factor depending on the solar collector area was examined on an annual basis.

The air data for the Mentese region where the villa is located is taken from the meteorology general directorate for 2015-2016 years. It is observed that the average temperature of the outside air does not fall below $5{ }^{\circ} \mathrm{C}$ during the winter season. This is ideal for use with air-based heat pumps. The fact that wind speed values are stable throughout the year creates an ideal environment for the use of air source heat pumps. Because high wind speeds at low temperatures interfere with heat transfer in the heat exchanger, making it difficult to absorb heat on the surface of the solar collector by the fluid.

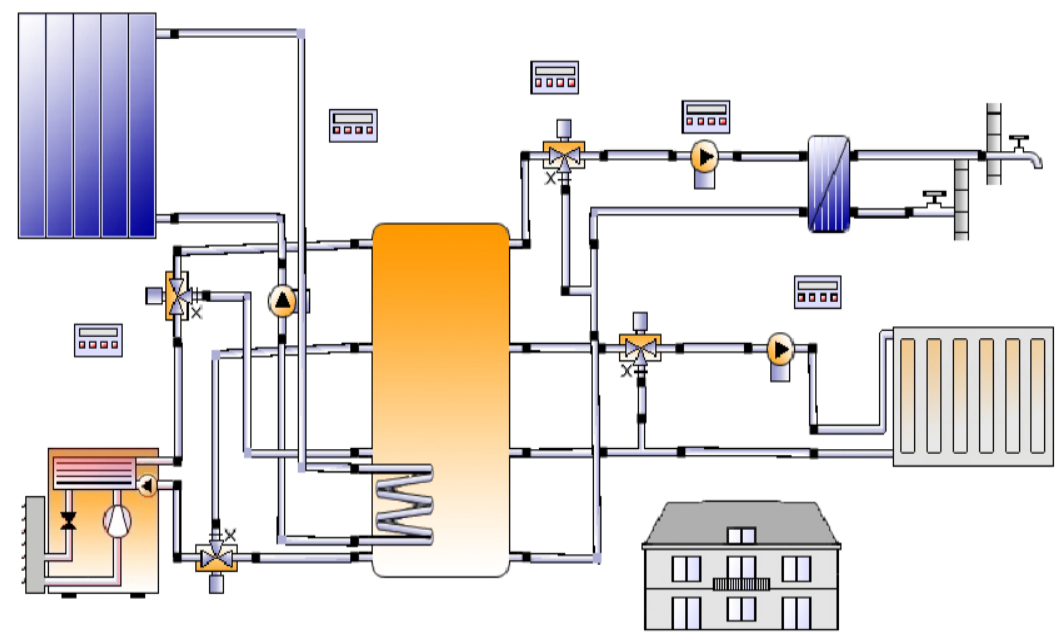

Figure 1. Solar collectors and air source heat pump supported heating system (Vela Solaris).

Villa's annual heating energy requirement and heat loss calculations were made using the TS 825 Building Thermal Insulation Rules and TS 2164 Heating System Project Procurement Rules standards. In the heat loss calculation, the outside temperature was taken as $-3{ }^{\circ} \mathrm{C}$ and calculated for floor and ceiling temperatures for nonheated areas according to this temperature. However, the values taken from the meteorology in the case of heat energy were used as the outdoor temperature and the temperatures of the unheated areas were found by interpolation and extrapolation. In both calculations, the values specified in the standard for room temperatures were accepted. The basic parameters of the solar collector, accumulation tank and circulation pumps used in the annual heating energy requirement and domestic hot water of the Villa were given in Table 1. 
Table 1. Basic parameters related to energy consumption of villa

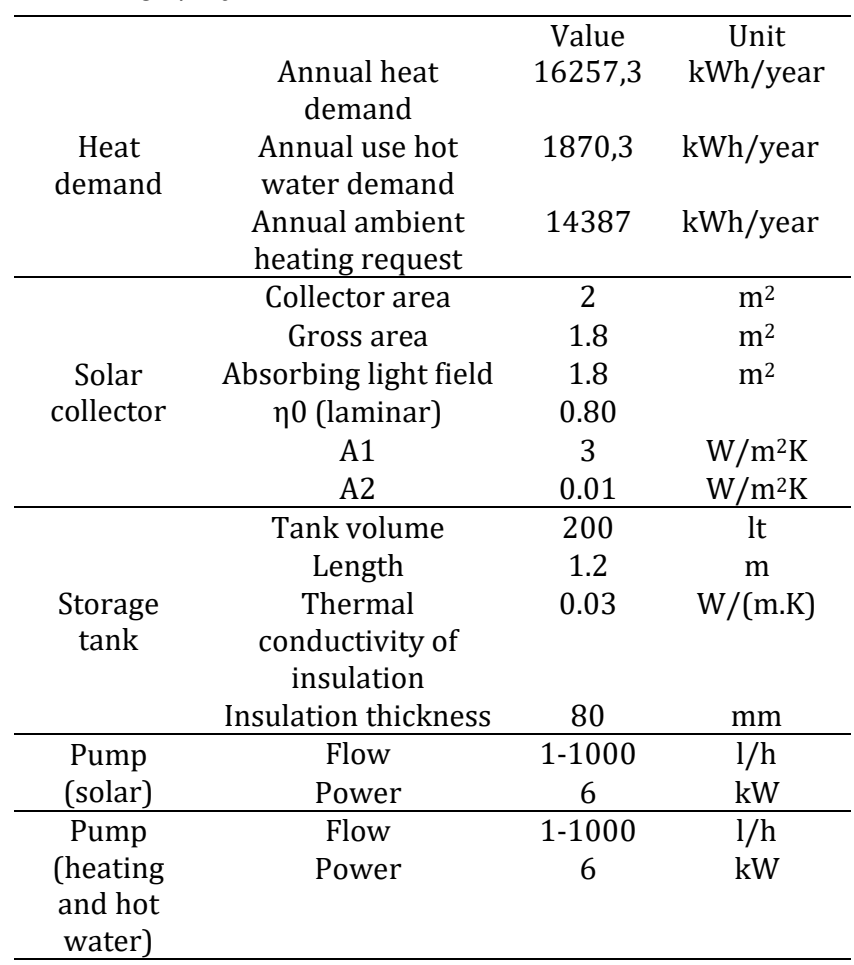

\section{Results and Discussion}

The energy demand of the house is constant, so it is expected that the thermal energy given to the heating system will be constant. However, since the heat pump alone cannot meet the demand, it is expected to increase the thermal energy given to the heating system to meet the demand due to the increase in the collector area. The existing heat pump (at $6.51 \mathrm{~kW}$ of power) can supply $11823 \mathrm{kWh}$ of energy to the system even if it is supported by the collector with $20 \mathrm{~m} 2$ area. It was seen that $73 \%$ of the respondents were satisfied when the energy demand of the housing was considered as $16257.3 \mathrm{kWh}$. The variation of the thermal energy given to the heating system depending on the collector was given in Fig. 2. The variation of the COP of the heat pump with respect to the collector area was shown in Fig. 3, and it can be seen that the $\mathrm{COP}_{\mathrm{HP}}$ is constant.

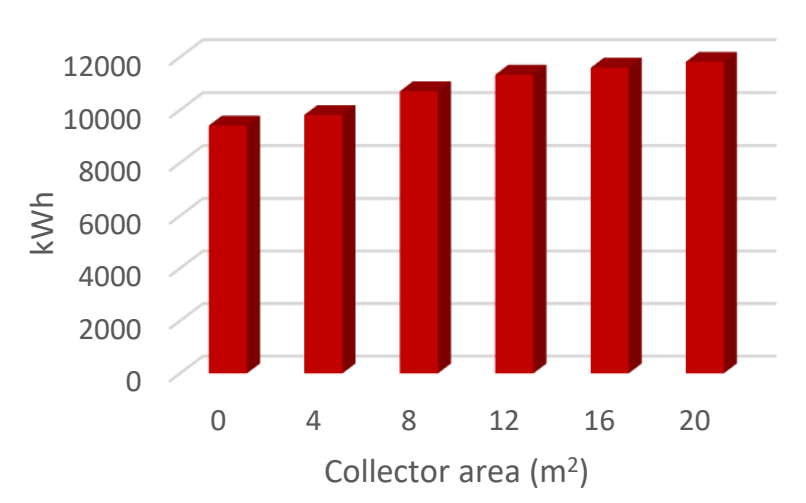

Figure 2. The change in thermal energy for $6.51 \mathrm{~kW} \mathrm{HP.}$

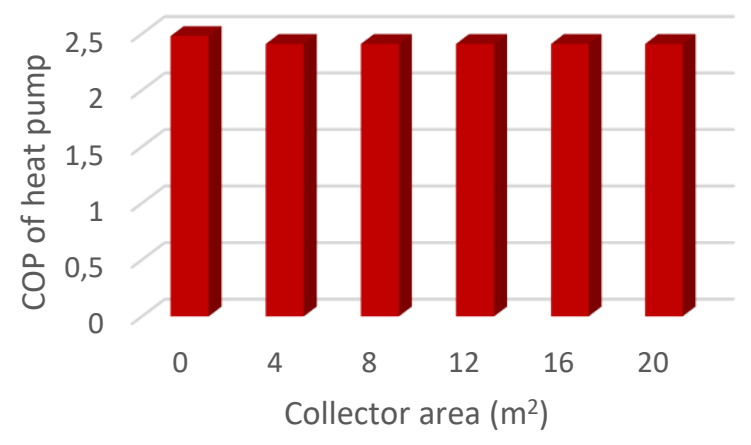

Figure 3. Variation of COP for heat pump power of 6.51 $\mathrm{kW}$.

The energy demand of the house is constant, so it is expected that the thermal energy given to the heating system will be constant. However, the heat pump at 7.98 $\mathrm{kW}$ power cannot meet the demand stand-alone. It is expected that the increase of the thermal energy given to the heating system due to the increase in the collector area to meet the demand (Fig. 4). A large number of collectors are needed to meet the demand with solar collectors. This situation reduces the economics of the systems and their applicability especially in apartment buildings. For this reason, it has not been feasible to select a heat pump at small capacity. The heating effect coefficient of the heat pump decreases when the first collector is added and then appears to be constant. This is due to the fact that the use of hot water in the summer period is met by two collectors and the increase in the collector area does not reduce the heat pump contribution to the system in winter.

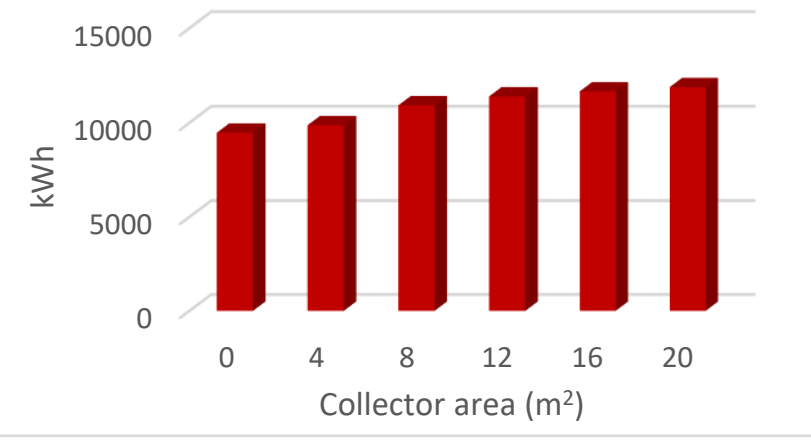

Figure 4 . The change in thermal energy for $7.98 \mathrm{~kW}$ HP.

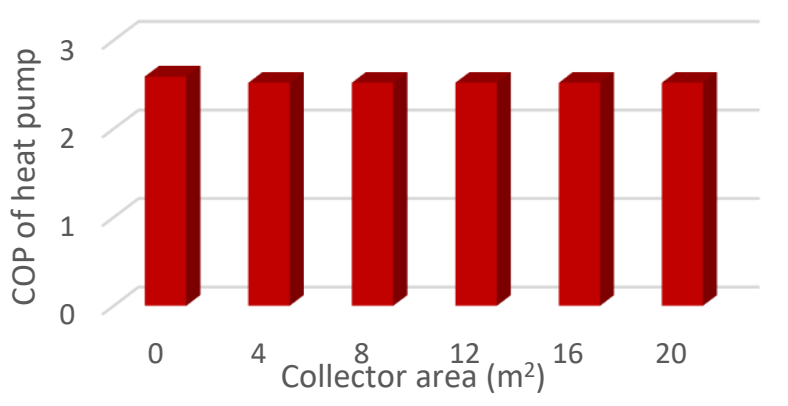

Figure 5. Variation of COP for heat pump power of 7.98 $\mathrm{kW}$. 
The change in thermal energy given to the system according to collector field is given in Fig. 6. Although the demand for heating is a constant value, since the energy demand cannot be met, there is a continuous increase due to the collector field. As the collector field increases, the heat pump's ( $9.95 \mathrm{~kW}$ power) COP value declines for the first time and then remains stable. The decrease in COP value is due to solar energy supply of hot water demand in June-September. The reason for the steady state is that the heating demand cannot be met and the heat pump continues to operate at the same power (Fig. 7).

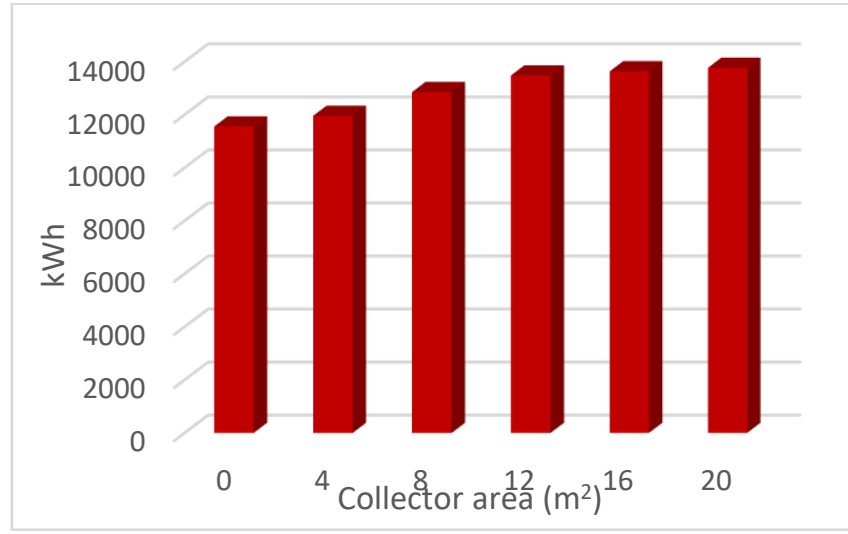

Figure 6. The change in thermal energy for $9.95 \mathrm{~kW} \mathrm{HP.}$

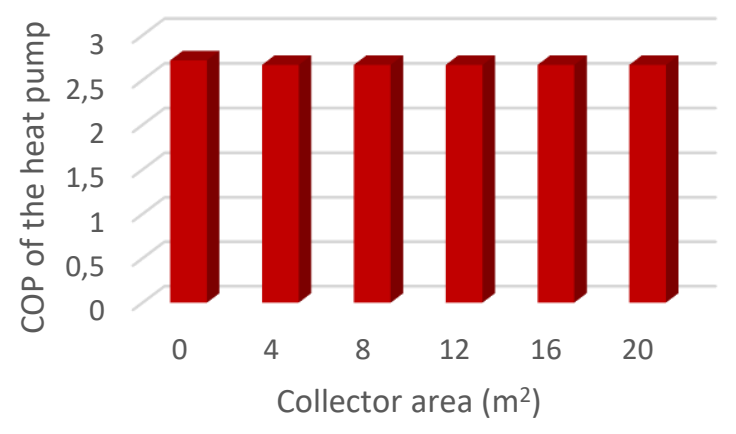

Figure 7. Variation of COP for heat pump power of 9.95 $\mathrm{kW}$.

The energy demand is stable and the heat pump in the $12.54 \mathrm{~kW}$ capacity can meet the demand alone. Figure 8 shows that increasing the collector field caused a slight increase in the amount of energy supplied to the housing. This situation is explained in the simulation program like that the energy received from thermal sources (heat pump and solar collector) should always be equal or higher to the demand of the house. Figure 9 shows the variation of the COP of the heat pump depending on the collector field. By increasing the collector field, the share of solar energy in the system increased and the efficacy of the heat pump decreased in the system. The heat pump's low capacity operation and to continuously running up, cut-out decreased the performance of heat pump.

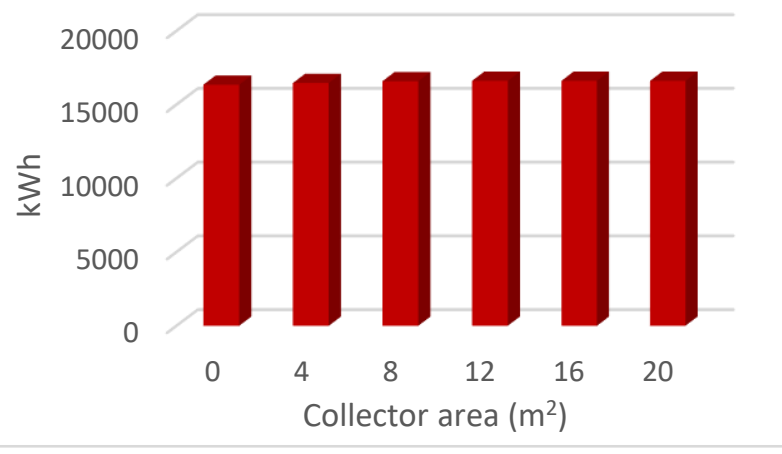

Figure 8. The change in thermal energy for $12.54 \mathrm{~kW}$

HP.

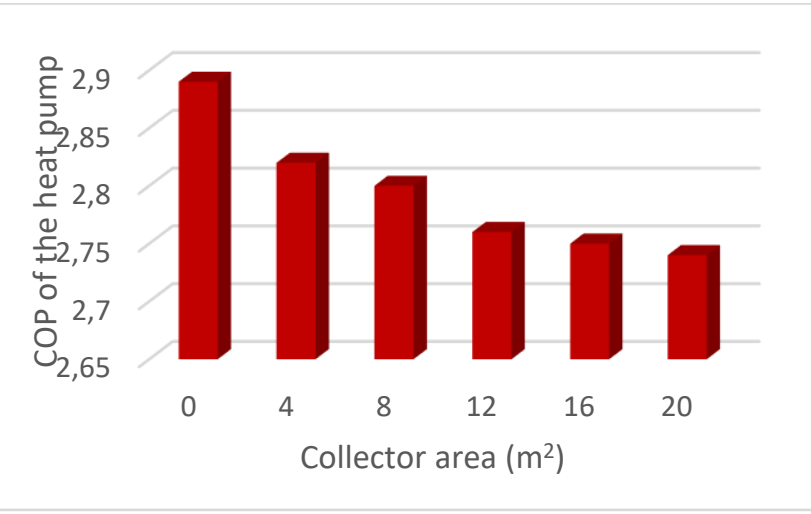

Figure 9. Variation of COP for heat pump power of 12.54 $\mathrm{kW}$.

The energy demand is stable and the heat pump at the $15.34 \mathrm{~kW}$ capacity can meet the demand stand-alone. Figure 10 shows that increasing the solar collector field caused a slight increase in the amount of energy supplied to the house. This situation is explained in the simulation program that the energy received from thermal sources (heat pump and solar collector) should always be equal or higher to the demand of the house. The change in the COP of the heat pump depending on the collector area is shown in Fig. 11. By increasing the collector field, the share of solar energy in the system increased and the efficacy of the heat pump decreased in the system. The heat pump's low capacity operation and to continuously running up, cut-out decreased the performance of heat pump.

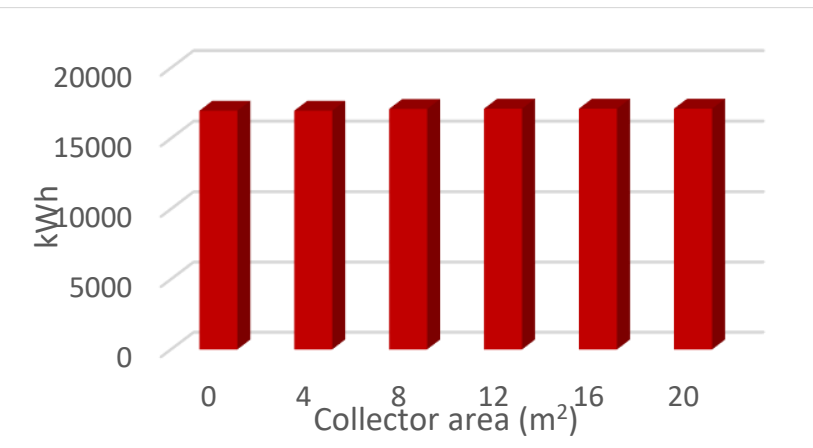

Figure 10. The change in thermal energy for $15.34 \mathrm{~kW}$ HP. 


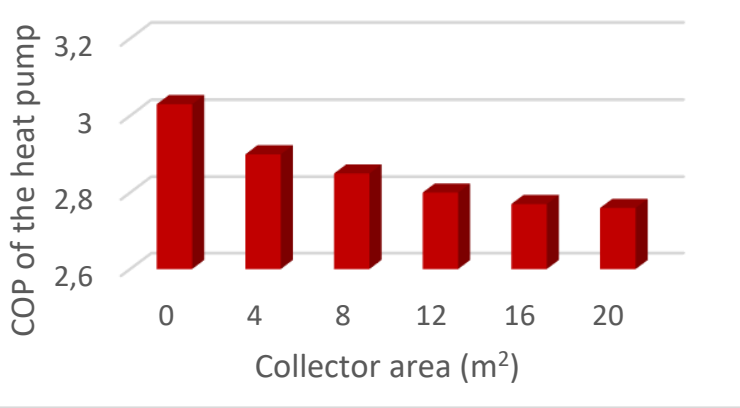

Figure 11. Variation of COP for heat pump power of $15.34 \mathrm{~kW}$.

The percentage change in the amount of electricity consumed to meet the energy demand in the heating system is given in Figure 12. The systems in which the solar collectors were not used were considered as reference conditions and the percentages of the decrease in electricity consumption depending on the increase of the collector area were compared for five different power heat pumps.

In the heat pumps with power ratings of 6.51, 7.98 and $9.95 \mathrm{~kW}$, the consumption of electricity seems to remain constant despite the change of the solar collector field. This is due to insufficient heat pump capacity selection. Even when ten collectors $\left(20 \mathrm{~m}^{2}\right)$ were added, the energy demand could not be met. For this reason, the amount of electric energy consumed by the heat pump and supplied thermal energy to the system from the heat pump remained constant. When the collector area was $4 \mathrm{~m}^{2}$, in the summer period (June-September), the consumption of hot water was provided from the solar energy and the electricity consumption decreased. At the same time, the same electricity consumption was realized for $8,12,16$, $20 \mathrm{~m}^{2}$ collector area.

The percentage change in the performance factor of the heating system where the collector is not used is shown in Fig. 13. The performance factors of the heating systems increase with the increase of the collector area. This is due to the fact that primary energy source is not used while benefiting from solar energy. Compared to the rate of change in the performance factors of the heating systems, the increase in the heating systems in which the heat pumps of $6.51,7.98$ and $9.95 \mathrm{~kW}$ are used is found to be more. This is because the capacities of the heat pumps are insufficient, so that each added collector is derived from the thermal energy of the system without changing the amount of thermal energy that the heat pump gives to the system. The rate of change in the performance factor is low in heating systems where 12.54 and $15.34 \mathrm{~kW}$ heat pumps meet the energy demand. The reason for this is that as the collector area increases, the amount of thermal energy that the heat pump gives to the system decreases.

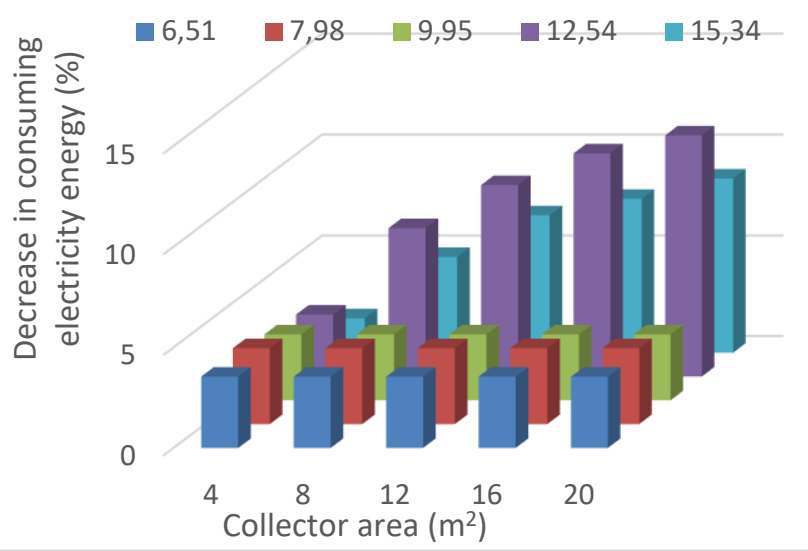

Figure 12. Percentage change in saved electricity energy on heating process when the collector is not used.

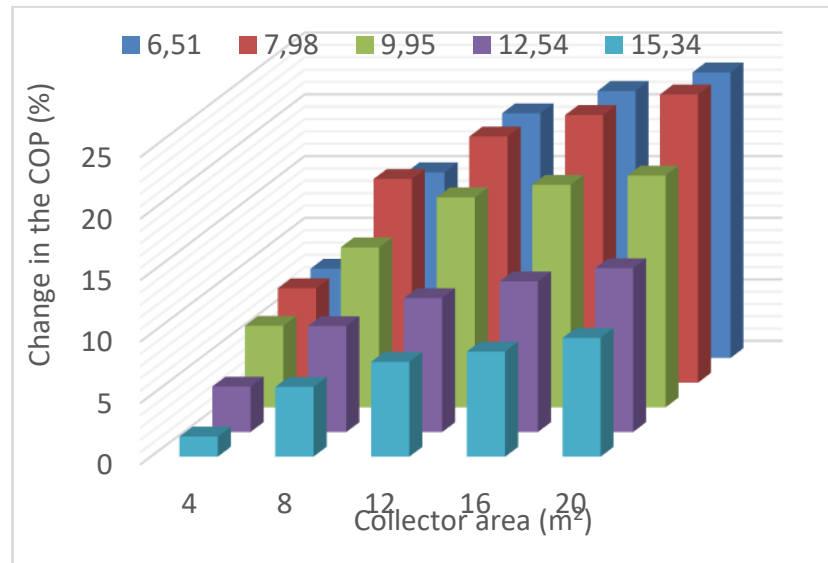

Figure 13. Percentage change in COP of heating system when the collector is not used.

\section{Conclusion}

In the heating system, 30 different models were simulated by changing the heat pump capacity and collector area in order to select the most suitable combination for the villa. In these simulations, the air-towater heat pump was investigated at five different capacities: $6.51 \mathrm{~kW}, 7.98 \mathrm{~kW}, 9.95 \mathrm{~kW}, 12.54 \mathrm{~kW}$ and $15.34 \mathrm{~kW}$. Another parameter used in the simulation was the number or area of the collector. Flat plate solar collectors ranging from 0 to $20 \mathrm{~m}^{2}$ were used for the numbers 0 to 10 . Models were produced by changing the heat pump capacity and collector area and modeled with POLYSUN, a semi-dynamic simulation program. Villa's annual heating energy requirement was $14386,5 \mathrm{kWh}$, heat loss was calculated as $13586 \mathrm{~W}$ per hour, indoor temperature was accepted as $20{ }^{\circ} \mathrm{C}$ in the program. Among the 30 different system models examined, the most applicable systems were the systems using 12.54 $\mathrm{kW}$ and $15.34 \mathrm{~kW}$ heat pump and two collectors. Two collectors were sufficient to meet the need for hot water for four months between June and September. Increased collector areas increased the performance of the heating system but reduced the $\mathrm{COP}_{\mathrm{HP}}$. In addition, increasing the collector area increased the cost of the initial installation and made it more difficult to find a place to install, 
especially in buildings. The results obtained were as follows:

Inadequate selection of the heat pump capacity resulted in a failure of the simulation program in the event that the final energy demand and hot water requirement cannot be met. Even with the addition of ten collectors to the heating system, the air-to-water heat pumps at power of $6.51 \mathrm{~kW}, 7.98 \mathrm{~kW}$ and $9.95 \mathrm{~kW}$ were found to meet $73.2 \%, 73.5 \%$ and $85 \%$ of the current demand respectively. Electricity consumption was reduced to 1 $\mathrm{kWh}$ because the collector with a gross area of $4 \mathrm{~m}^{2}$ was added to the heating system with heat pump and the summer use hot water needs to be supplied from the collectors. For this reason, the heating effect coefficient at these three capacities, which cannot be satisfied, decreases only in the models in which two collectors were passed from zero collector. Increasing the solar collector area from $4 \mathrm{~m}^{2}$ to $20 \mathrm{~m}^{2}$ due to the low capacity of the heat pump did not cause a change in the amount of electricity and the amount of electricity the heat pump gave to the system. In the systems where the number of collectors changed from 2 to 10 , it was seen that the heating effect coefficient remained constant. The performance factor were increased from 2.42 to 3.29 . However, performance factors did not matter as these systems cannot meet demand.

Increasing the collector area in the $12.54 \mathrm{~kW}$ and 15.34 $\mathrm{kW}$ heat pumps, where the heat pump capacity was sufficient to meet the demand, reduced the energy consumption and electricity consumption by the heat pump. While the amount of thermal energy supplied to the system remained the same, the reduction in total electricity consumption increased the performance factor of the system. The performance factor reached the result of an increase from 2.86 to 3.31 .

The number of solar collectors was between 0 and 10 , and the gross area was between 0 and $20 \mathrm{~m}^{2}$. Increasing the number of solar collectors increased the performance of the heating and hot water preparation system from 2.42 to 3.31 . Because only the circulation pumps draw electricity when the solar energy was supplied to the system. At the same time, the performance factor of the system increased while the heat pump's COP value decreased. While the number of collectors was increased from 0 to 10 , the COP of the heat pump decreased from 3.03 to 2.74 . This was due to the working principle of the heat pump. Heat pumps operate at high efficiency with high evaporator and low condenser temperature. The reduction in the difference between the well and the source temperature makes heat transfer from the condenser to the tank difficult. The COP of the heat pump is reduced due to the increase in the temperature in the tank by using collector and the full capacity of the heat pump cannot be operated.

\section{References}

[1] Dikici, A. (2004) Experimental investigation of ground source, solar source and air source heat pump for domestic heating in Elazığ, Ph.D., Firat University, Elazığ, 211s.

[2] Gündüz, A.B. (2007) The performance of a solarassisted heat pump water heating system in Bilecik, MS, Eskișehir Osmangazi University, Eskișehir, 123s.

[3] Açlkgöz Ö. (2007) The investigation of solar energy support in a combined energy system, MS, Yıldız Technical University, Istanbul, 103s.

[4] Liang C., Zhang, X., Li, X. and Zhu, X. (2011) Study on the performance of a solar assisted air source heat pump system for building heating, Energy and Buildings, 43 : 2188-2196.

[5] Deng, S., Dai, Y.J. and Wang, R.Z. (2013) Performance optimization and analysis of solar combi-system with carbon dioxide heat pump, Solar Energy, 98 : 212-225.

[6] Aydın, A. (2013) Experimental observation of water heater on the collector with vacuum tube supported with heat pump, M.Sc., Karabük University, Karabük, 41s.

[7] Carbonell, D., Haller, M.Y. and Frank, E. (2014) Potential benefit of combining heat pumps with solar thermal for heating and domestic hot water preparation, Energy Procedia, 57 : 2656-2665.

[8] González, J.P., Yousif, C. (2015) Prioritising energy efficiency measures to achieve a zero net-energy hotel on the island of Gozo in the central Mediterranean, Energy Procedia, $83: 50$ - 59.

[9] Good, C., Andresen, I. and Hestnes, A.G., (2015) Solar energy for net zero energy buildings - A comparison between solar thermal, PV and photovoltaicthermal (PV/T) systems, Solar Energy, 122 : 986996.

[10] Bessa, V.M.T. and Prado, R.T.A. (2015) Reduction of carbon dioxide emissions by solar water heating systems and passive technologies in social housing, Energy Policy, 83 : 138-150.

[11] Ghafoor, A. and Fracastoro, G.V., (2015) Costeffectiveness of multi-purpose solar thermal systems and comparison with PV-based heat pumps, Solar Energy, 113 : 272-280.

[12] Shipkovs, P., Snegirjovs, A, Shipkovs, J., Kashkarova, G., Lebedeva, K. and Migla, L., 2015. "Solar thermal cooling on the northernmost latitudes", Energy Procedia 70: 510-517.

[13] Good, C.S., Lobaccaro, G. and Hårklau, S. (2014) Optimization of solar energy potential for buildings in urban areas - a Norwegian case study, Energy Procedia, 58 : 166-171.

[14] Bornatico, R., Hüssy, J., Witzig, A. and Guzzella, L. (2013) Surrogate modeling for the fast optimization of energy systems, Energy, 57 : 653-662. 